\title{
PERMASALAHAN YANG DIHADAPI GURU DALAM PENGELOLAAN DAN PEMANFAATAN MEDIA PEMBELAJARAN
}

\author{
Dwi Prastika ${ }^{1}$, Santhy Hawanti ${ }^{2}$, Lia Mareza ${ }^{3}$ \\ ${ }^{123}$ Program Studi Pendidikan Guru Sekolah Dasar Universitas Muhammadiyah \\ Purwokerto \\ dwiprastika21@gmail.com ${ }^{1}$
}

\begin{abstract}
The main focus of this research is the problem of the management and use of instructional media by teachers. This study aims to determine the teacher's problems in the management of instructional media and find out the teacher's problems in utilizing instructional media as a source of learning in State Elementary School 2 Kalisalak. In this study using a descriptive qualitative approach, and data collection techniques include observation, interviews, and documentation. The results of the study show that the teacher's problematics in managing the media for procurement provided by schools is incomplete, so each teacher chooses by designing the media and utilizing the surrounding environment to be used as media, inventory recording is still united with the needs of the school, there is no special room for storage of learning media, and the storage is still lacking maintenance, because there is no special staff to handle media storage. The next result is the problematic teacher in the use of instructional media, in the learning process low-grade teachers more often use the surrounding environment as a medium of learning, the LCD media but only a few teachers can use the $L C D$.
\end{abstract}

Keywords: Problems, Management Media Utilization, elementary schools

\begin{abstract}
Abstrak
Fokus utama dalam penelitian ini yaitu problematika pengelolaan dan pemanfaatan media pembelajaran oleh guru. Penelitian ini bertujuan untuk mengetahui problematika guru dalam pengelolaan media pembelajaran dan mengetahui problematika guru dalam memanfaatkan media pembelajaran sebagai sumber belajar di SD Negeri 2 Kalisalak. Dalam penelitian ini menggunakan pendekatan kualitatif deskriptif, dan teknik pengumpulan datanya meliputi observasi, wawancara dan dokumentasi.. Hasil penelitian menunjukkan bahwa, prolematika guru dalam pengelolaan media pembelajaan untuk pengadaan yang disediakan sekolah tidak lengkap, sehingga masingmasing guru memilih dengan cara merancang media dan memanfaatkan lingkungan sekitar untuk dijadikan sebagai media, pencatatan inventarisasi masih disatukan dengan keperluan sekolah,tidak adanya ruangan khusus untuk penyimpanan media pembelajaran, dan tempat penyimpanannya masih terlihat kurangnya terawat, karena tidak adanya tenaga khusus untuk menangani penyimpanan media. Hasil selanjutnya problematika guru dalam pemanfaatan media pembelajaran, dalam proses belajar guru kelas rendah lebih sering memanfaatkan lingkungan sekitar dijadikan sebagai media pembelajaran, adanya media LCD tetapi hanya beberapa guru yang dapat menggunakan LCD.
\end{abstract}

Kata Kunci: Permasalahan, Pengelolaan, Pemanfaatan Media, Sekolah Dasar 


\section{PENDAHULUAN}

Perkembangan ilmu pengetahuan dan teknologi semakin mendorong upaya-upaya pembaharuan dalam pemanfaatan hasil-hasil teknologi dalam proses belajar mengajar. Para guru dituntut agar mampu menggunakan alat-alat yang dapat disediakan oleh sekolah, dan tidak tertutup kemungkinan bahwa alat-alat tersebut sesuai dengan perkembangan dan tuntutan zaman. Guru sekurang-kurangnya dapat menggunakan alat yang murah dan bersahaja tetapi merupakan keharusan dalam upaya mencapai tujuan pengajaran yang diharapkan.Disamping mampu menggunakan alat-alat yang tersedia, guru juga dituntut untuk dapat mengembangkan alat-alat yang tersedia, guru juga dituntut untuk dapat mengembangkan keterampilan membuat media pengajaran yang akan digunakannya apabila media tersebut belum tersedia

Media pembelajaran adalah media yang digunakan untuk mendukung aktivitas pembelajaran yaitu mempresentasikan atau menyajikan informasi dan pengetahuan baik kepada individu maupun kelompok. (Pribadi, 2017; Sumantri \& Rachmadtullah, 2016). Selain itu, ketidaksesuaian materi dengan media pembelajaran menjadikkan guru untuk mencari media lain sebagai penggantinya
(Iasha, Sumantri, Sarkadi \& Rachmadtullah, 2018).

Dalam suatu proses belajar mengajar, dua unsur yang sangat penting adalah metode mengajar dan media pengajaran (Yustitia, V \& Fanny, A. M. 2019). Kedua aspek ini saling berkaitan. Pemilihan salah satu metode mengajar tertentu akan mempengaruhi jenis media pengajaran yang sesuai, meskipun masih ada berbagai aspek lain yang harus diperhatikan dalam memilih media, antara lain tujuan pengajaran, jenis tugas dan respon yang diharapkan siswa kuasai setelah pengajaran berlangsung, dan konteks pembelajaran termasuk karakteristik siswa (Rachmadtullah, R., Iasha,Rasmitadila, Sofyan, 2019). Meskipun demikian, dapat dikatakan bahwa salah satu fungsi utama media pengajaran adalah sebagai alat bantu mengajar yang turut mempengaruhi iklim, kondisi, dan lingkungan belajar yang ditata dan diciptakan oleh guru (Iasha et al, 2019).

Media pembelajaran digunakan sebagai alat bantu untuk mempermudah dan membantu tugas guru dalam menyampaikan berbagai bahan dan materi pelajaran, serta mengefektifkan dan mengefisienkan anak didik dalam memahami materi dan bahan pelajaran tersebut (Rachmadtullah, et al 2018). Dengan adanya media pembelajaran, anak didik dapat belajar dengan mudah dan merasa senang dalam mengikuti pelajaran. 
Biasanya, anak didik dapat dengan mudah menangkap materi pelajaran bila pembelajaran yang diselenggarakan tersebut menyenangkan. Umumnya media pembelajaran itu dikemas dengan cara yang menarik (Rachmadtullah, Zulela \& Sumantri, 2019).

Mengemukakan bahwa media pembelajaran yang digunakan sebagai alat bantu dalam peroses belajar mengajar berfungsi untuk membangkitkan keinginan dan minat baru, membangkitkan motivasi dan ransangan kegiatan belajar dan bahkan membawa pengaruh psikologis terhadap siswa. Dengan demikian penggunaan media pengajaran dapat membawa manfaat besar terhasap keberhasilan pelaksanaan kegiatan belajar mengajar di kelas.

Sedangkan penyajiannya disampaikan secara menarik dan disesuaikan dengan karakteristik anak didik. Sehingga anak didik akan dengan mudah mencerna pelajaran tersebut. Dengan demikian, tujuan pembelajaran pun akan tercapai dengan efektif dan efisien.

Pengelolaan adalah sarana dan prasarana pendidikan untuk meningkatkan kualitas pembelajaran yang dibatasi oleh pengelolaan, pengadaan, pemanfaatan dan pemeliharaan yang sudah berjalan (Megasari, 2014). Kualitas dalam mengelola dibatasi dengan pengadaan yang telah diadakan, karena tidak semua pembelajaran menggunakan media yang dsediakan. Kesesuaian guru dalam memanfaatkan media pembelajaran dapat terlihat dengan keprofeionalannya yang ditunjukkan oleh guru.

Pengelolaan diadakan untuk dikelola pihak sekolah dengan baik. Terdapat beberapa pengelolaan diantaranya pengadaan media pembelajaran, inventarisasi, pemeliharaan dan penyimpannan. Pengadaan adalah perlengkapan pendidikan yang pada dasarnya merupakan upaya untuk merealisasikan rencana pengadaan perlengkapan yang telah disusun sebelumnya (Bafadal, 2008).

Rencana pengadaan media pembelajaran disusun secara sistematis agar media yang didapatkan, mendapatkan bantuan sarana dan prasarana pendidikan dari pemerintah untuk dikelola sebagai bahan ajar. Media pembelajaran didapatkan melalui berbagai cara untuk memperolehnya diantaranya, yaitu (1) pembelian dengan biaya, (2) pembelian dengan biaya SPP, (3) bantuan dari masyarakat lainnya.

Inventarisasi adalah pencatatan dan penyusunan daftar barang milik Negara secara sistematis, tertib dan teratur berdasarkan ketentuan-ketentua atau pedoman-pedoman yang brelaku. Kegiatan inventarisasi merupakan kegiatan pencattan 
dan pemberian kode untuk media pembelajaran.

Pemeliharaan adalah kegiatan penjagaan atau pencegahan dari kerusakan suatu barang, sehingga barang tersebut kondisinya baik dan siap digunakan. Kegiatan pemeliharaan dimulai dari pemakaian barang, yaitu dengan cara hatihati dalam menggunakannya (Matin, 2017)

Pemeliharaan media pembelajaran untuk menjaga keadaan media agar layak terpakai dan terawatt dengan baik (Fanny, \& Suardiman, 2013). Bafadal (2008: 49) ada beberapa macam pemeliharaan perlengkapan pendidikan di sekolah. Ditinjau dari sifatnya, ada empat macam pemeliharan perlengkapan pendidikan di sekolah diantaranya (1) pemeliharaan yang bersifat pengecekan, pemeliharaan ini dilakukan dengan cara mengecek media pembelajaran secara rutin agar tidak kotor, (2) pemeliharaan yang bersifat pencegahan yatu dengan cara pencegahan, dengan cara menyimpan media ditempatkan khusus agar kapasitas media tetap baik, (3) pemeliharaan yang bersifat perbaikan ringan yaitu pemeliharaan berupa mempebaiki media yang rusak, pemeliharaan yang bersifat berbaikan berat yaitu perbaikan ini berat membutuhkan biaya yang tidak cukup banyak.

Pengelolaan dan pemanfaatan media pembelajaran menjadi salah satu yang harus diperhatikan guru. Berdasarkan hasil observasi yang telah dilakukan terhadap guru di SD Negeri 2 Kalisalak, dalam pelaksanaan pembelajaran telah menggunakan media pembelajaran. Namun, dalam pengelolaan media masih belum dilakukan dengan baik. Hal tersebut menjadikan guru merasa kesulitan untuk mengakses atau memanfaatkan kembali saat dibutuhkan karena pengelolaan yang belum rapi dan jelas tempatnya. Guru perlu memiliki kemampuan mengelola dan memanfaatkan media pembelajaran. Hal ini penting dipahami mengingat meda menjadi salah satu penunjang keberhasilan pembelajaran. Dengan pemanfaatan dan pengelolaan baik, guru, peserta didk, dan sekolah akan mendapat manfaat yang maksimal. Manfaat yang jelas-jelas dapat dirasakan adalah proses pembelajaran menjadi lebih menarik dengan keberadaan media yang menunjang, di samping itu pengelolaan media yang tepat juga menjadikan pemeliharaan dan pemanfaatan media dapat berjalan lebih efektif. Penelitian ini berupaya untuk mengetahui permasalahan permasalahan yang dihadapi oleh guru di SD Negeri 2 Kalisalak. Penelitian ini menjadi penting dilakukan karena selama ini segala bentuk permasalahan dalam pemanfaatan dan pengelolaan media pembelajaran masih sebatas pada keluh kesah dan belum 
teridentifikasi dengan jelas sehingga tidak dapat disampaikan penjelasan dari permasalahan yang dihadapi sekolah.

\section{METODE}

Penelitian ini menggunakan pendekatan kualitatif dengan metode deskriptif, pengumpulan data menggunakan kata-kata dan gambar. Satori (2014) menjelaskan bahwa penelitian kualitatif bersifat deskriptif dengan mendeskripsikan sesuatu berarti menggambarkan suatu kejadian yang terjadi,. Menuangkan suatu tulisan, laporan penelitian kualitatif berisi kutipan-kutipan dari data atau fakta yang diungkap di lapangan untuk memberikan ilustrasi yang utuh dan untuk memberikan dukungan terhadap data yang disajikan. Penelitian ini dilakukan dengan mendeskripsikan permasalahan yang akan peneliti temukan di lapangan.

Penelitian kualitatif adalah metode penelitian yang dgunakan untuk meneliti pada kondisi objek yang alamiah, (sebagai lawannya adalah eksperimen) dimana peneliti adalah sebagai instrument kuncu, analisis data bersifat induktif, dan hasil penelitian kualitatif lebih menekankan makna dari pada generalisasi. Peneliti dapat menemukan permasalahan dilengkapi dengan data-data secara jelas mengenai permasalahan pengelolaan dan pemanfaatan media pembelajaran oleh guru di sekolah.

Partisipan dalam penelitian ini adalah orang yang dapat memberikan informasi. Partisipan dalam penelitian yang terdiri kepala sekolah dan beberapa guru diantaranya guru kelas I, II, III, IV, V dan VI. Sumber dalam penelitian ini adalah subjek data yang didapatkan peneliti. Dalam penelitian ini peneliti menggunakan sumber data primer dan sekunder. Sumber data primer yaitu data yang langsung dikumpulkan oleh peneliti dari sumber pertama. Adapun yang menjadi dumber primer dalam penelitian ini adalah kepala sekolah dan guru kelas I, II, III, IV, V dan VI Sumber data sekunder yaitu data yang langsung dikumpulkan oleh peneliti sebagai penunjang dari sumber pertama. Sumber data sekunder ini adalah kepala sekolah.

Teknik pengumpulan data dalam penelitian ini menggunakan teknik observasi, wawancara dan dokumentasi:

\section{Observasi}

Observai dilakukan untuk mencari data yang akan diketahui peneliti. Creswell (2013) menjelaskan bahwa observasi yang di dalamnya peneliti langsung turun ke lapangan untuk mengamati perilaku dan aktivitas individu-individu di lokasi 
penelitian. Dalam pengamatan ini peneliti, merekam atau mencatat baik dengan cara terstruktur maupun semistruktur misalnya, dengan mengajukan sejumlah pertanyaan yang memang diketahui peneliti, aktivitasaktivitas dalam lokasi penelitian. Peneliti kualitatif dapat terlihat dalam peran-peran yang beragam, mulai dari sebgai non partisipan hingga partisipa utuh.

Tujuan dilakukannya observasi ini adalah untuk mengetahui permasalahan dalam pengelolaan media dan pemanfaata media oleh guru. Observasi dilakukan untuk memperoleh data yang mendukung penelitian permasalahan dalam pengelolaan dengan mencari informasi pengadaan, inventarisasi, pemeliharaan, penyimpanan dan permasalahan pemanfaatan media pembelajaran oleh guru dalam proses pembelajaran di sekolah.

\section{Wawancara}

Wawancara merupakan suatu kegiatan yang dilakukan untuk mendapatkan informasi secara langsung dengan mengajukan pertanyaan antara pewawancara dengan yang diwawancarai. Sugiyono (2010: 72) menjelaskan bahwa wawnacara digunakan sebagai teknik pengumpulan data apabila peneliti ingin melakukan studi pendahuluan untuk mengemukakan yang harus diteliti, dan juga apabila peneliti ingin mengetahui ha-hal dari responden yang lebih mendalam. Wawancara yang digunakan semistruktur (semistructure interview), jenis wawancara ini termasuk dalam kategori indept interview, dalam pelaksanaannya lebih bebas dibandingkan dengan wawancara terstruktur. Tujuan dari wawancara ini adalah untuk menemukan permasalahan secara lebih terbuta, dimana pihak yang diajak wawancara diminta pendapat ide-idenya. Narasumber wawanacara ini dilakukan kepala sekolah dan beberapa guru diantaranya guru kelas I, II, III, IV dan V. Terkait permasalahan pengelolaan dan pemanfaatan media pembelajaran oleh guru.

\section{Dokumentasi}

Dokumentasi merupakan hasil penelitian dokumen seperti foto hasil rekaman, atau sumber karya tulis akademik yang ada. Sugiyono (2010: 82) menjelaskan bahwa dokumentaasi merupakan catatan peristiwa yang sudah berlalu. Data bisa berbentuk tulisan, gambar ataupun karyakarya monumental seseorang. Dokumen yang digunakan oleh peneliti dalam penelitian ini meliputi foto kondisi pemeliharaan, tempat penyimpanan dan dokumentasi wawancara partisipan. Teknik analisis data dalam penelitian ini dilaksanakan scara terus-menerus sejak sebelum memasuki lapangan, selama di lapangan, dan setelah 
selesai di lapangan. Menurut Miles \& Huberman (Sugiyono, 2010) komponen analisis dataa interaktif.

\section{Data Reduction}

Data yang diperoleh dari lapangan jumlahnya cukup banyak, oleh karena itu perlu dicatat secara teliti dan rinci, sehingga segera dilakukan analisis data melalui reduksi data. Mereduksi data berarti merangkum, memilih hal-hal pokok, memfokuskan pada hal-hal yang penting, dicari tema dan polanya.

\section{Data Display}

Data direduksi setelah itu langkah selanjutnya adalah mendisplaykan data. Penyajian data dilakukan dalam bentuk uraian singkat, bagan, hubungan antar kategori, flowchart dan sejenisnya. Menyajikan data dalam penelitian kualitatif diberikan secara naratif untuk memahami apa yang terjadi. Peneliti harus selalu menguji apa yang telah ditemukan pada saat memasuki lapangan yang masih bersifat hipotesis itu berkembang atau tidak, setelah lama memasuki lapangan ternyata hipotesis dirumuskan selalu didukung oleh data pada saat dikumpulkan di lapangan maka akan berkembang menjadi teori grounded. Teori grounded adalah teori yang ditemukan secara induktif, berdasarkan data-data yang ditemukan di lapangan, dan selanjutnya diuji melalui pengumpulan data secara terusmenerus.

\section{Conclucions}

\section{Drawing/Verification}

\section{(Kesimpulan/Verifikasi)}

Langkah ketiga adalah penarikan kesimpulan dan verifikasi. Kesimpulan yang dikemukakan pada tahap awal, didukung oleh bukti-bukti yang valid dan konsisten saat peneliti kembali ke lapangan mengumpulkan data, maka kesimpulan yang dikemukakan merupakan kesimpulan yang dapat dipercaya.

\section{Pengujian Keabsahan Data}

Pengujian keabsahan data pada penelitian ini menggunakan triangulasi. Sugiyono (2010: 125) berpendapat bahwa triangulasi diartikan sebagai pengecekan data dari berbagai sumber dengan berbagai cara, dan berbagai waktu.

\section{HASIL DAN PEMBAHASAN}

Hasil penelitian dan pembahasan untuk permasalahan pengelolaan dan pemanfaatan media pembelajaran oleh guru di SD Negeri 2 Kalisalak. Hasil penelitian mengidentifikasi yang selanjutnya akan menjelaskan beberapa hal yang akan dibahas sebagai (1) Permasalahan pengelolaan media pembelajaran oleh guru. (2) Permasalahan pemanfaatan media pembelajaan oleh guru. 
Deskripsi hasil penelitian akan dibahas satu per satu sub bab tersebut. Berikut ini adalah deskripsi hasil dan pembahasan penelitian:

\section{Permasalahan Pengelolaan Media Pembelajaran}

Pengelolaan media pembelajaran itu sangat penting untuk dikelola, karena dengan adanya pengelolaan semua media dapat dimanfaatkan secara maksimal. Megasari (2014: 637) menyatakan bahwa sarana dan prasarana pendidikan sebagai salah satu dari unsur manajemen pendidikan yang memiliki peranan penting dalam proses belajar mengajar, sarana dan prasarana pendidikan merupakan hal yang tidak boleh diabaikan. Informasi yang didapat dari kepala sekolah menjelaskan bahwa pengelolaan media pembelajaran di SD Negeri 2 Kalisalak belum maksimal dikarenakan terdapat kendala. Meliputi:

\section{Permasalahan Pengadaan Media}

\section{Pembelajaran}

Berdasarkan dari hasil wawancara kepala sekolah dan guru di SD Negeri 2 Kalisalak, pengadaan media melalui dana BOS dan bantuan wali murid yang dipergunakan untuk pembelian media pembelajaran. Matin (2017) menjelaskan pengadaan merupakan fungsi operasional pertama dalam manajemen sarana dan prasarana pendidikan persekolahan, serangkaian kegiatan untuk menyediakan sarana dan prasarana persekolahan sesuai dengan kebutuhan.

\section{Permasalahan inventarisasi Media pembelajaran}

Kepala sekolah menjelaskan bahwa inventarisasi yang ada di SD Negeri 2 Kalisalak masih disatukan dengan data-data keperluan sekolah. Hal ini dikarenakan tidak ada tenaga khusus untuk pendataan media pembelajaran yang ada.

\section{Permasalahan Pemeliharaan Media Pembelajaran}

Dapat disampaikan bahwa proses pemeliharaan media pembelajaran di sekolah dan di kelas belum terselenggara dengan baik dan belum, karena pemeliharaan meliputi pengecekan, pencegahan, perbaikan ringan (Bafadal, (2008)

\section{Permasalahan Penyimpanan Media Pembelajaran}

Berdasarkan hasil wawancara yang didapatkan kepala sekolah dan guru kelas di SD Negeri 2 Kalisalak bahwa dapat disimpulkan untuk penyimpanan media ditempatkan di perpustakaan sebagian terdapat di masing-masing kelas. Namun untuk penyimpanannya belum baik, 
dikarenakan tidak adanya tenaga khusus yang menangani penyimpanan.

\section{Permasalahan Pemanfaatan Media Pembelajaran}

Salah satu bentuk keterampilan yang harus dimiliki guru adalah keterampilan memanfaatkan media pembelajaran. Namun demikian, masih banyak juga guru yang mengalami kesulitan menggunakan media untuk menunjang pembelajaran di kelas. Diantaranya:

1. Keterbatasan IT. Terdapat beberapa guru yang memiliki keterbatasan penggunaan teknologi, seperti tidak dapat mengoprasikan penggunaan LCD

2. Media yang ada tidak sesuai dengan kebutuhan materi dan dengan kondisi peserta didik. Kebutuhan guru dalam mengajar menyesuaikan materi, adanya media yang tidak sesuai menjadikan guru untuk memiliki kreativitas untuk mencari media lain.

3. Keterbatasan jumlah media sehingga harus bergantian dengan guru lain. Seperti media pembelajaran LCD, digunakan secara bergantian karena media LCD di SD Negeri 2 Kalisalak terdapat 3 buah LCD.

4. Tidak semua media yang disediakan sekolah sesuai untuk pengajaran di kelas.

\section{KESIMPULAN}

Berdasarkan deskripsi hasil dan pembahasan penelitian di atas, dapat peneliti simpulkan bahwa, Tidak adanya ruangan khusus untuk penyimpanan media, sehingga penyimpanan di perpustakaan. Untuk penyimpanan dikelas, masih banyaknya media yang tersimpan kurang rapi bersamaan dengan tumpukan buku. Pemanfaatan media pembelajaran, masih banyaknya guru yang tidak dapat memanfaatkan LCD sebagai pembelajaran, karena kurangnya menguasai teknologi informatika.

\section{DAFTAR PUSTAKA}

Bafadal, I. (2008). Manajemen Perlengkapan Sekolah Teori dan Aplikasinya. Jakarta: Bumi Aksara.

Creswell. Jhon (2013). Reserch Design Pendekatan Kualitatif, Kuantitatif, dan Mixed. Yogyakarta: Pustaka Belajar.

Fanny, A. M., \& Suardiman, S. P. (2013). Pengembangan multimedia interaktif untuk mata pelajaran ilmu pengetahuan sosial (IPS) sekolah dasar kelas V. Jurnal Prima Edukasia, 1(1), 1-9.

Iasha, V., Rachmadtullah, R., Sudrajat, A., \& Hartanti, D. 2019. The Impact 
Interactive Learning Media on The Learning Outcomes of Fifth Grade

Social Science Knowledge in Elementary Schools.

Iasha, V., Sumantri, M. S., Sarkadi, S., \& Rachmadtullah, R. 2018. Development Media Interactive Learning in Education Pancasila and Citizenship Education to Improve Tolerance of Students in Elementary School. In Annual Civic Education Conference (ACEC 2018). Atlantis Press.

Matin dan Nurhattati. (2017). Manajemen

Sarana dan Prasarana Pendidikan. Depok: Rajawali Pers.

Megasari, R (2014). Peningkatan Pengelolaan Sarana dan Prasarana Pendidikan untuk Meningkatkan Kualitas Pembelajaran di SMPN 5 Bukittinggi. Jurnal Administrasi Pendidikan. Vol 2. Hal 636-831.

Pribadi, A Benny. (2017). Media dan Teknologi dalam Pembelajaran. Jakarta: Kencana.

Rachmadtullah, R., Iasha, V., Rasmitadila., Sofyan, H. 2019. CD-Based Interactive Multimedia on Integrative Thematic Learning in Elementary School.International Conference on Technology and Educational Science. https://eudl.eu/doi/10.4108/eai.21-11$\underline{2018.2282040 .}$.

Rachmadtullah, R., Ms, Z., \& Sumantri, M. S. (2018). Development of computerbased interactive multimedia: study on learning in elementary education. Int. J. Eng. Technol, 7(4), 2035-2038.

Rachmadtullah, R., Nadiroh, N., Sumantri, M. S., \& Zulela, M. S. 2018. Development of Interactive Learning Media on Civic Education Subjects in Elementary School. In Annual Civic Education Conference (ACEC 2018). Atlantis Press.

Rachmadtullah, R., Zulela, M. S., \& Sumantri, M. S. 2019. Computer-based interactive multimedia: a study on the effectiveness of integrative thematic learning in elementary schools. In Journal of Physics: Conference Series (Vol. 1175, No. 1, p. 012028). IOP Publishing.

Satori, D. (2014). Metodologi Penelitian Kualitatif. Bandung: Alfabeta.

Sugiyono. (2010). Memahami Penelitian Kualitatif. Bandung: Alfabeta.

Sumantri, M. S., \& Rachmadtullah, R. (2016). The effect of learning media and self regulation to elementary students' history learning 
outcome. Advanced

Science

Letters, 22(12), 4104-4108.

Yustitia, V \& Fanny, A. M. (2019, March). Analysis Of Pedagogical Skills And Readiness Of Elementary School Teachers In Support Of The Implementation Of The 2013 Curriculum. In International Conference on Bussiness Law and Pedagogy (Vol. 1, No. 1, pp. 59-63). 